
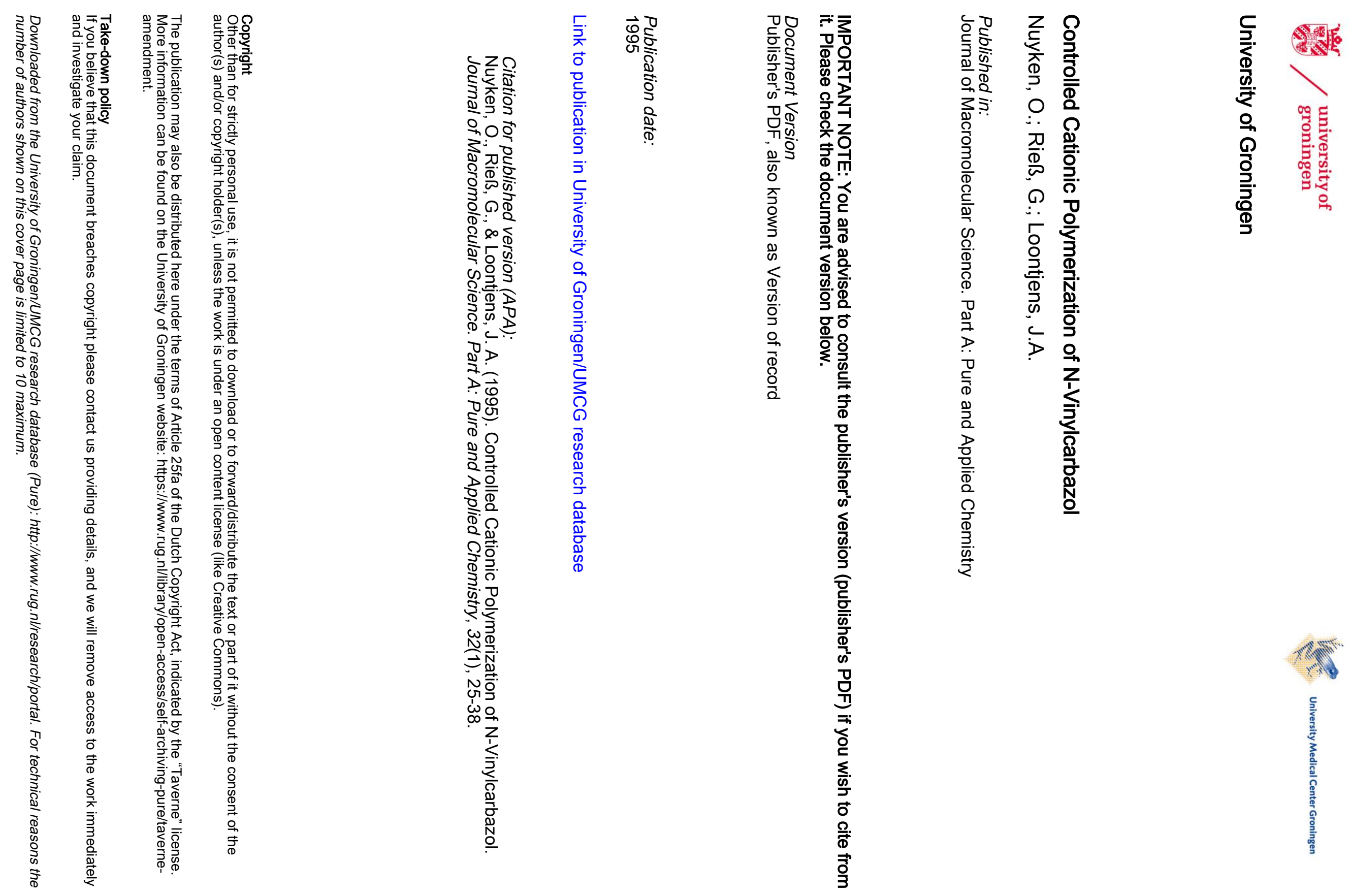


\title{
CONTROLLED CATIONIC POLYMERIZATION OF N-VINYLCARBAZOL
}

\author{
o. Nuyken*, G, Rieß \\ Lehrstuhl für Makromolekulare stoffe \\ Technische Universität München \\ Lichtenbergstr. 4, D-85747 Garching, Germany \\ J.A. Loontjens \\ $D S M, R \& D$, PO Box 18 \\ NL-6160 MD Geleen, The Netherlands
}

\begin{abstract}
Cationic polymerization of N-Vinylcarbazol (NVC) was initiated with 1-iodo-1-(2-methylpropyloxy) ethane (1) in the presence of $\mathrm{N}(\mathrm{n}-\mathrm{Bu}){ }_{4} \mathrm{ClO}_{4}$ and without addition of this activator. Furthermore, 1-chloro-1-(2-methylpropyloxy)ethane (2), with and without activator has been applied as initiator for NVC. These initiating systems show remarkable differences in activity, which are discussed in detail.
\end{abstract}

INTRODUCTION

$\mathrm{N}$-vinylcarbazol (NVC) is very reactive towards Bronsted and Lewis acids and other cationic initiators ${ }^{1,2}$. Due to this reactivity, its polymerization is rather fast and therefore difficult to control. Normally, low concentrations of monomer and initiators and low temperatures are applied. Neither molar masses nor their distribution were controlled. This situation has 
improved with the discovery of "living" systems for NVC by Higashimura et $a l^{3-5}$. Recently, an alternative route for cationic living polymerization was found in our laboratory ${ }^{6-8}$, in which 1-iodo-1-(2-methylpropyloxy) ethane (1) $/ \mathrm{N}(\mathrm{n}-\mathrm{Bu})_{4} \mathrm{ClO}_{4}$ was used for the polymerization of vinylether.

Excellent control of molar masses over a wide range and narrow molar mass distributions observed for different vinylethers forced us to study scope and limitation of this initiating system for NVC.

\author{
RESULTS AND DISCUSSION \\ INITIATION OF NVC WITH $1 / \mathrm{N}(\mathrm{n}-\mathrm{Bu})_{4} \mathrm{ClO}_{4}$
}

The polymerization of NVC was carried out at low temperatures in dichloromethane according to the following reaction scheme:<smiles>CC(C)COC(C)I</smiles>

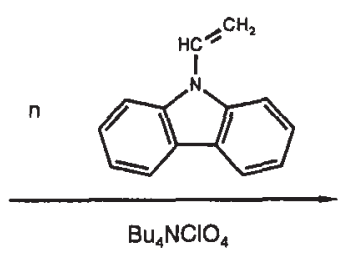<smiles>CCCOC(C)CCn1c2ccccc2c2ccccc21</smiles><smiles>CC(C)OCCn1c2ccccc2c2ccccc21</smiles><smiles>CCO</smiles><smiles>CC(C)OCCCn1c2ccccc2c2ccccc21</smiles> 


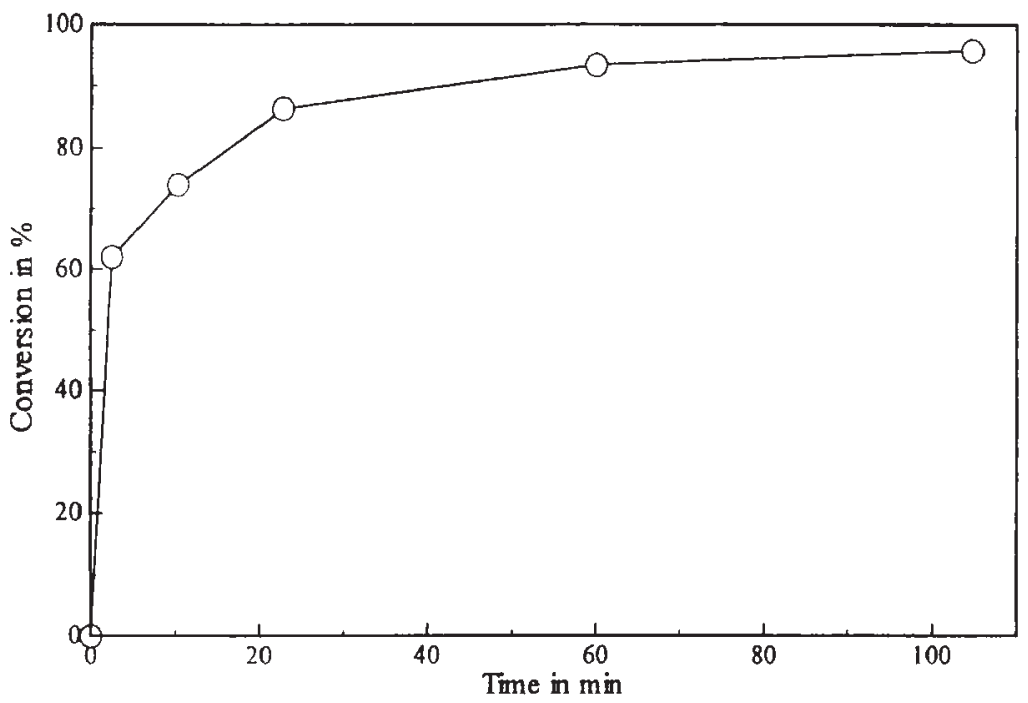

FIG. 1: Polymerization of $\mathrm{NVC}$ in $\mathrm{CH}_{2} \mathrm{Cl}_{2}$ at $-70^{\circ} \mathrm{C}$ $[\mathrm{NVC}]_{0}=0,46 \mathrm{~mol} 1^{-1},[1]=0,0055 \mathrm{~mol} 1^{-1}$ $\left[\mathrm{N}(\mathrm{n}-\mathrm{Bu}){ }_{4} \mathrm{ClO}_{4}\right]=0,0097 \mathrm{~mol} 1^{-1}$

A typical experiment is presented in FIG. 1 and TABLE 1. The theoretical molar masses were calculated on the basis of the following equations:

$M_{n}($ calc. $)=M_{M} \cdot[M]_{0} /[I] \cdot C+M_{\text {Head }}+M_{\text {End }}$

$M_{M}=$ molar mass of the monomer

$M_{\text {Head }}=$ molar mass of the head group

$M_{\text {End }}=$ molar mass of the end group

$[I]=$ initial concentration of the initiator

$[\mathrm{M}]_{0}=$ initial concentration of the monomer

$\mathrm{C}=$ conversion

conversion was determined via ${ }^{1} \mathrm{H}$ NMR (Fig. 2)

$I_{1}+I_{2}+I_{3}=I_{M}+I_{p}$

$I_{1}=$ aromatic protons of monomer and polymer and one olefinic proton of the monomer 
TABLE 1
Polymerization of NVC in $\mathrm{CH}_{2} \mathrm{Cl}_{2}$ at $-70^{\circ} \mathrm{C}$ $[\mathrm{NVC}]_{0}=0,46 \mathrm{~mol} l^{-1},[1]=0,0055 \mathrm{~mol} \mathrm{l}^{-1}$ $\left[\mathrm{N}(\mathrm{n}-\mathrm{Bu})_{4} \mathrm{ClO}_{4}\right]=0,0097 \mathrm{~mol} 1^{-1}$

\begin{tabular}{|c|c|c|c|c|}
\hline $\begin{array}{c}t \\
\min \end{array}$ & $\begin{array}{l}\mathrm{C} \\
\div\end{array}$ & $\begin{array}{c}M_{n}(G P C)^{11} \\
g \operatorname{mol}^{-1}\end{array}$ & $\begin{array}{c}\mathrm{M}_{\mathrm{n}} \text { (calc.) } \\
\mathrm{g} \mathrm{mol}^{-1}\end{array}$ & $M_{w} / M_{n}$ \\
\hline 25 & 62,6 & 1980 & 10250 & 4,55 \\
\hline 10 & 73,9 & 2060 & 12080 & 5,0 \\
\hline 22,5 & 86,6 & 3240 & 14130 & 4,45 \\
\hline 60 & 93,5 & 3890 & 15240 & 3,97 \\
\hline 105 & 96,1 & 4130 & 15660 & 3,83 \\
\hline
\end{tabular}

1) calibrated with polystyrene standards

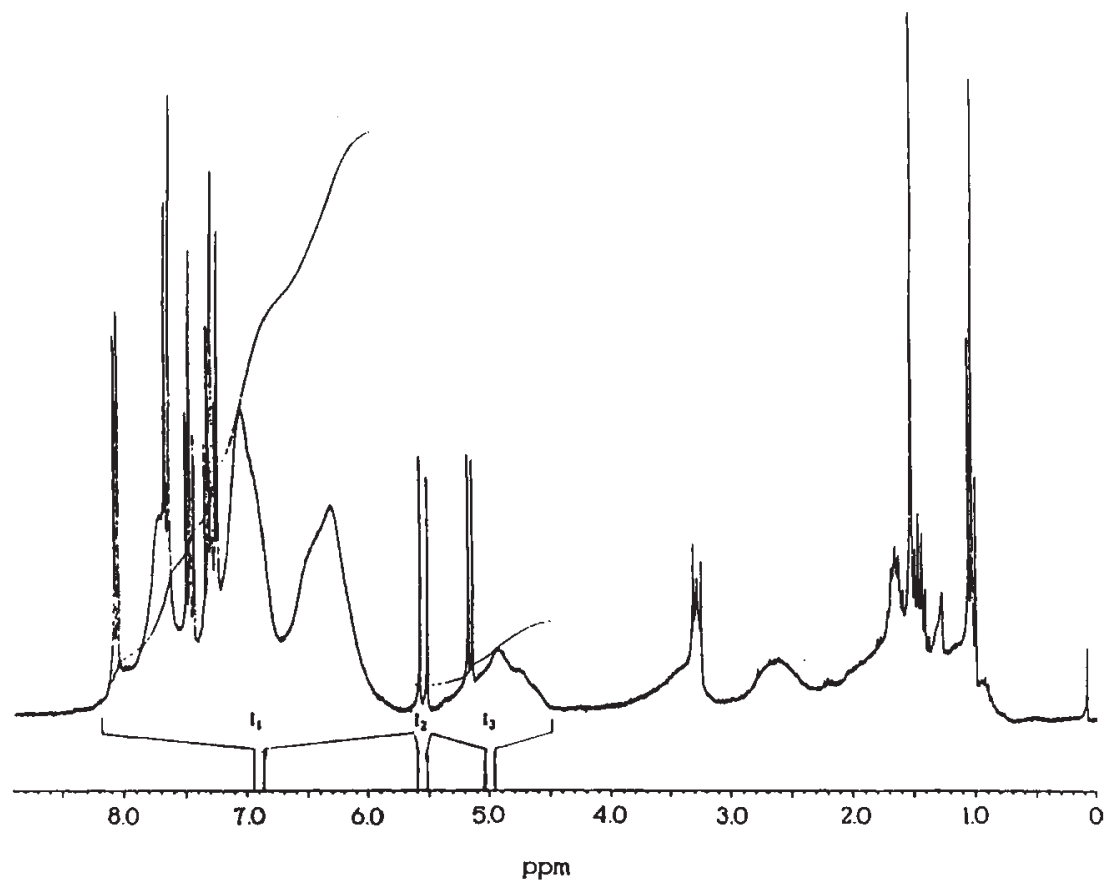

FIG. 2: ${ }^{1} \mathrm{H}$ NMR of Poly (NVC) in $\mathrm{CDCl}_{3}$ after $86 \%$ conversion 


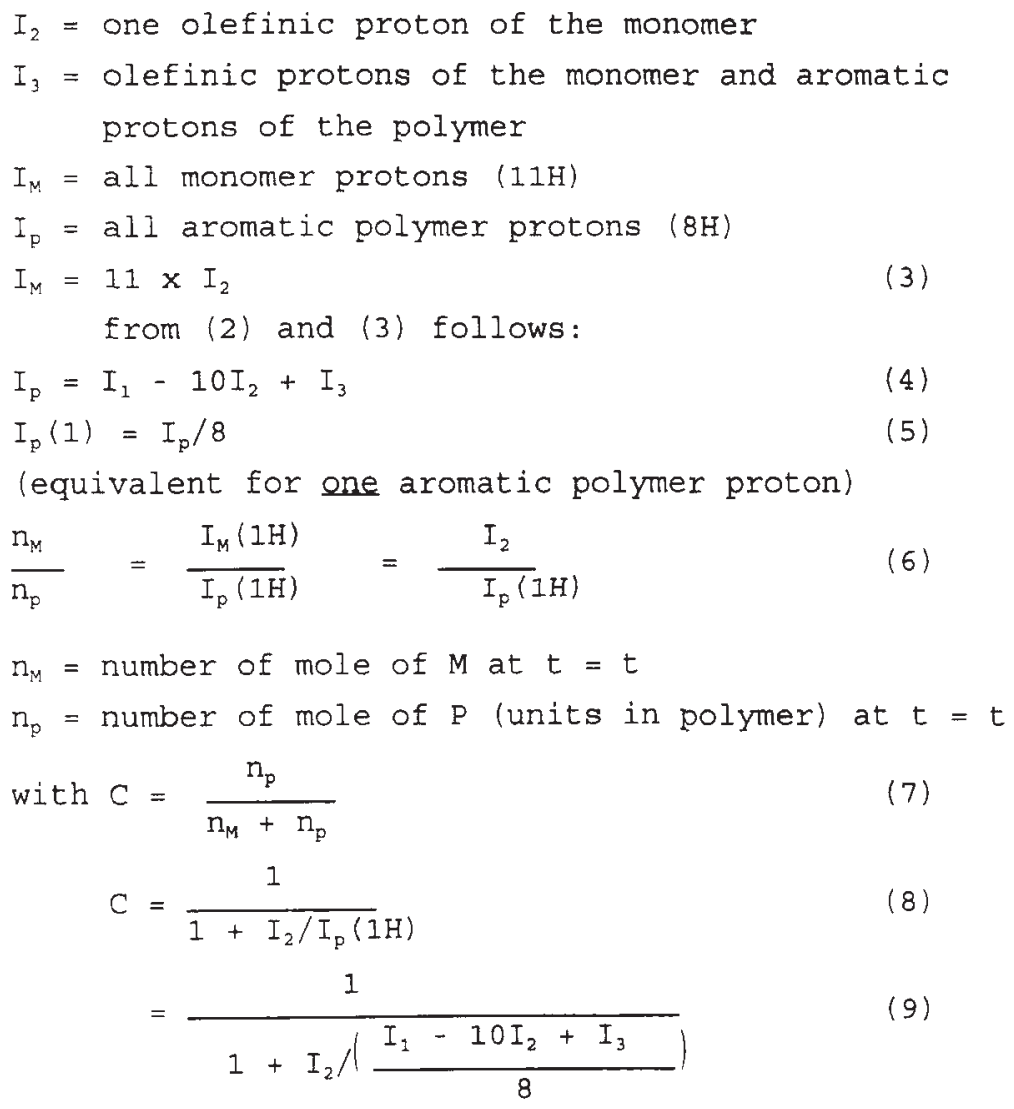

(equivalent for one aromatic polymer proton)

$\frac{n_{M}}{n_{p}}=\frac{I_{M}(1 \mathrm{H})}{I_{p}(1 \mathrm{H})}=\frac{I_{2}}{I_{p}(1 \mathrm{H})}$

As one can see from table 1 molar masses are not controlled by the ratio [M] : [I] - they are smaller than calculated. These results can be explained on the basis of chain transfer reaction taking place under conditions applied here.

\section{INITIATION WITH 1 (WITHOUT ACTIVATOR)}

The main reason for the rather disappointing results described in the former chapter are most likely due to transfer reactions. These side reactions can be reduced 
by suppressing the activity of active center (e.g. assuming that ion pairs are less active than free ions). This concept is successfully applied to ionic polymerizations (cationic polymerization: addition of donors ${ }^{9}$ anionic polymerization: conversion of a carbanion into a Grignard reagents for controlled termination with $\mathrm{CO}_{2}{ }^{10}$ ).

In case of the NVC polymerization, deactivation is realized by reducing of the activator (salt) concentration down to [activator] $=0$. The polymerization characteristics can be explained by including a reversible termination step into the reaction scheme ${ }^{11}$ :

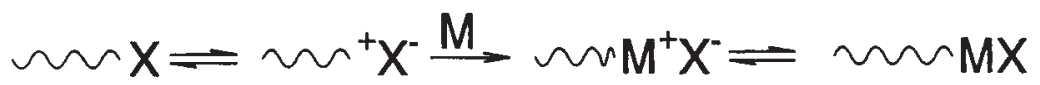

Table 2 summarizes results of a NVC polymerization initiated with 1 but without $\mathrm{N}(\mathrm{nBu})_{4} \mathrm{ClO}_{4}$. The polymerization is slower as in the presence of the activating salt even at temperatures 20 to 30 degree higher than applied before (table 1 ).

It is interesting to note that no polymerization was observed in toluene. However, increasing of polarity by addition of dichloromethane to toluene allows polymerization which becomes faster with increasing amount of $\mathrm{CH}_{2} \mathrm{Cl}_{2}$. Simultaneous with polarity broadening of the molar mass distribution was observed. Relatively good agreement between calculated and observed molar masses was found in all cases.

Molar masses increase linearelly with conversion. Conversion of the monomer was followed by GC using xylene as internal standard. 
TABLE 2:

Polymerization of NVC with 1

$t=2$ hrs, $[\mathrm{NVC}]_{0}=0,15 \mathrm{~mol}^{-1}$

\begin{tabular}{|c|c|c|c|c|c|c|}
\hline $\begin{array}{l}\mathrm{T} \\
{ }^{\circ} \mathrm{C}\end{array}$ & $\begin{array}{l}\text { [I] } \\
\text { mol } 1^{-1}\end{array}$ & solvent & $\begin{array}{l}\mathrm{C} \\
\%\end{array}$ & $M_{n}(G P C)$ & $M_{n}(\operatorname{calc})^{11}$ & $\mathrm{M}_{\mathrm{w}} / \mathrm{M}_{\mathrm{n}}$ \\
\hline-50 & 0,0069 & $\mathrm{CH}_{2} \mathrm{Cl}_{2}$ & 95 & 3940 & 4120 & 2,63 \\
\hline-50 & 0,0085 & $\begin{array}{l}\text { toluene } \\
\mathrm{CH}_{2} \mathrm{Cl}_{2} /\end{array}$ & 0 & - & - & - \\
\hline-50 & 0,0076 & $\begin{array}{c}\text { toluene } \\
\qquad 1: 3^{21}\end{array}$ & 22 & 1280 & 970 & 1,41 \\
\hline-50 & 0,0084 & $\begin{array}{l}\mathrm{CH}_{2} \mathrm{Cl}_{2} / \\
\text { toluene } \\
\quad 3: 1^{2)}\end{array}$ & 53 & 1720 & 1960 & 1,33 \\
\hline-40 & 0,0073 & $\mathrm{CH}_{2} \mathrm{Cl}_{2}$ & 100 & 5490 & 4100 & 2,31 \\
\hline-40 & 0,0073 & $\begin{array}{l}\text { toluene } \\
\mathrm{CH}_{2} \mathrm{Cl}_{2} /\end{array}$ & 0 & - & - & - \\
\hline-40 & 0,0075 & $\begin{array}{c}\text { toluene } \\
1: 3^{21}\end{array}$ & 33 & 1470 & 1410 & 1,36 \\
\hline-40 & 0,0078 & $\begin{array}{c}\mathrm{CH}_{2} \mathrm{Cl}_{2} / \\
\text { toluene } \\
\quad 3: 1^{23}\end{array}$ & 67 & 2520 & 2620 & 1,27 \\
\hline
\end{tabular}

1) calculated, using equ. 1

2) vol./vol. ratio 


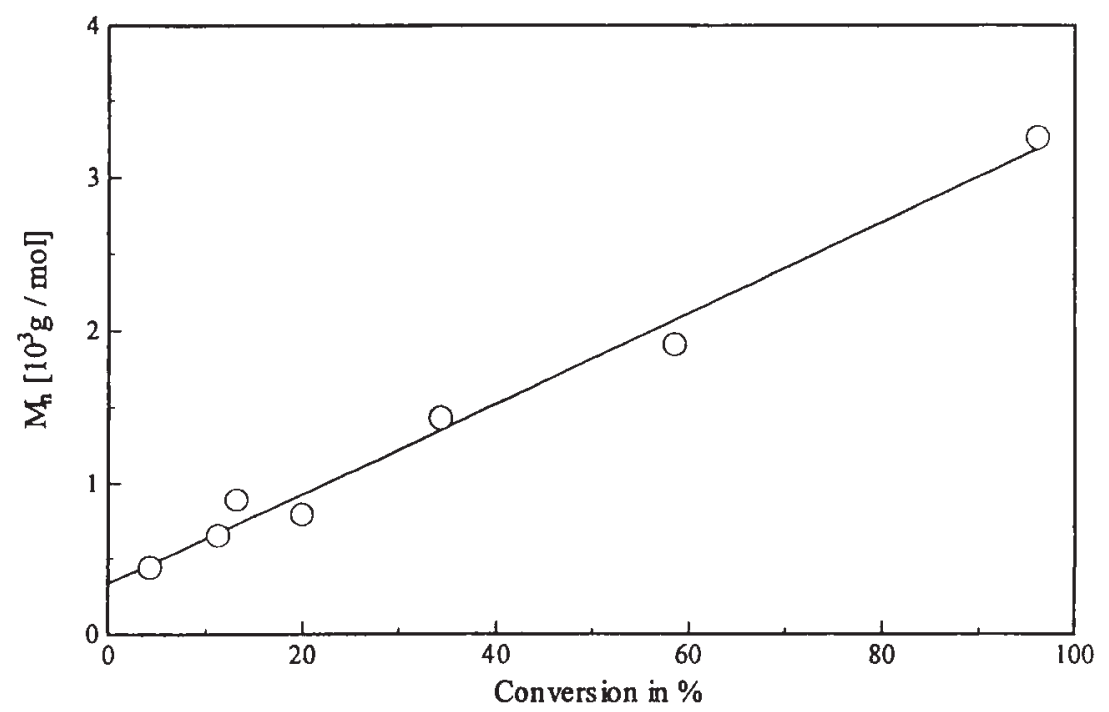

FIG. 3: Linear relationship between $M_{n}$ and conversion for the polymerization of $\mathrm{NVC}$ in $\mathrm{CH}_{2} \mathrm{Cl}_{2} /$ toluene at $-50^{\circ} \mathrm{C} \quad(3: 1$ vol. ratio) $[\mathrm{M}]=0,15 \mathrm{~mol} l^{-1},[I]=0,01 \mathrm{~mol}^{-1}$ $[\operatorname{salt}]=0$

$$
C=\frac{\left(A_{M} / A_{S t}\right)_{0}-\left(A_{M M} / A_{S t}\right)_{t}}{\left(A_{M} / A_{S t}\right)_{0}}
$$

$\left(A_{M} / A_{S t}\right)_{0}=$ ratio of $G C$ peaks of monomer/standard at $t=0$

$\left(A_{M} / A_{S t}\right)_{t}=$ ratio of $G C$ peaks of monomer/standard at $t=t$

The time conversion curve is given in Fig. 4.

Table 3 summarizes the results of a typical experiment. The discrepancy between calculated and observed molar masses is propably due to the calibration of the GPC with polystyrene standards.

$M_{n}$ (GPC) and $M_{n}$ (calc.) are getting closer with increasing molar masses meaning that the chemical nature 


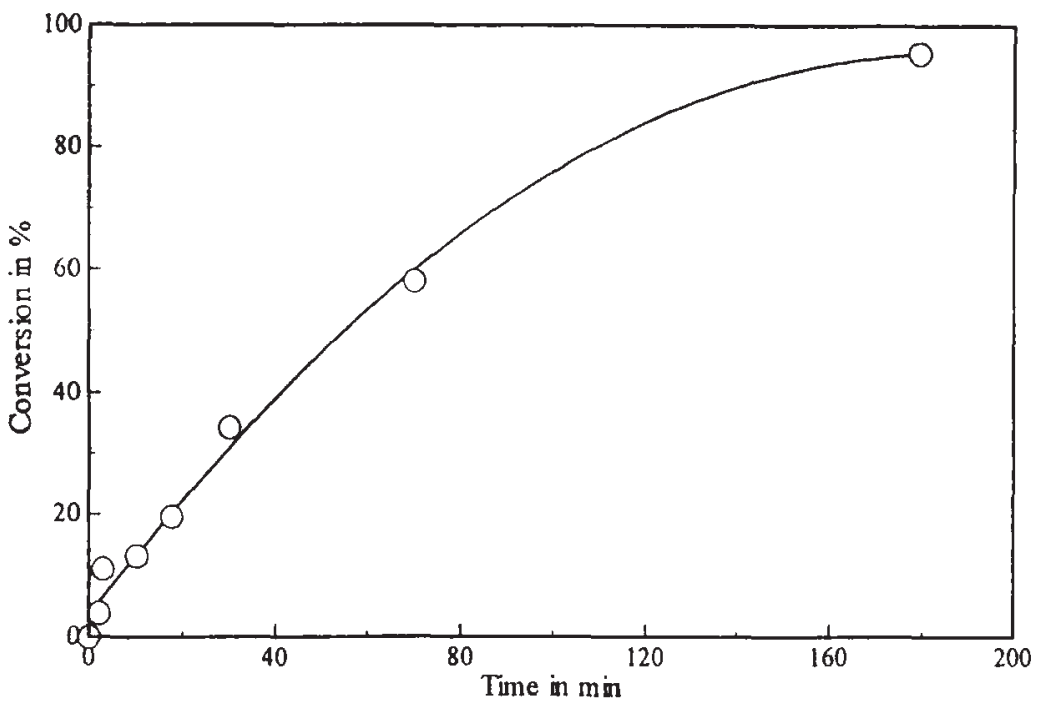

FIG. 4: Polymerization of NVC in $\mathrm{CH}_{2} \mathrm{Cl}_{2} /$ toluene $(3: 1)$, at $-50^{\circ} \mathrm{C}[\mathrm{NVC}]_{0}=0,15 \mathrm{~mol} 1^{-1},[1]=0,01 \mathrm{~mol} 1^{-1}$

TABLE 3:

Polymerization of NVC initiated by 1 in $\mathrm{CH}_{2} \mathrm{Cl}_{2} /$ toluene $(3: 1$ (vol)).

$[\text { NVC }]_{0}=0,15 \mathrm{~mol}^{-1},[1]=0,01 \mathrm{~mol} 1^{-1}, \mathrm{~T}=-50^{\circ} \mathrm{C}$

$\begin{array}{llllllll}t / \min & 2 & 3 & 10 & 15 & 30 & 70 & 180\end{array}$

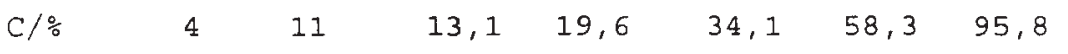

$\begin{array}{llllllll}M_{n}(G P C) & 440 & 650 & 880 & 800 & 1440 & 1930 & 3200\end{array}$

\begin{tabular}{|c|c|c|c|c|c|c|}
\hline$M_{n}(c a l c)$ & 250 & 450 & 510 & 700 & 1120 & 1820 \\
\hline
\end{tabular}

$\begin{array}{llllllll}M_{w} / M_{n} & 1,55 & 1,50 & 1,48 & 1,45 & 1,45 & 1,43 & 1,40\end{array}$

(GPC) 
becomes less important for the separation process of the GPC column with increasing molar masses.

The consumption of monomer follows first order kinetics (Fig. 5)

$-d[M] / d t=k^{\prime}[M]$

$k^{\prime}=k$ [1]

The growing chains remain active or can be activated again. This was clearly demonstrated by a monomeraddition-experiment in which, after 100\%-consumption of a first portion of monomer a second portion leads to an increase of molar masses (Table 4).

This observation opens an interesting perspective for the synthesis of block copolymers by a sequential addition of different monomers ${ }^{12}$.

INITIATION WITH 1-CHLORO-1 (2-METHYLPROPYLOXYETHANE) (2) WITH AND WITHOUT $\mathrm{N}(\mathrm{n}-\mathrm{Bu}){ }_{4} \mathrm{ClO}_{4}$.

It would be of great advantage if initiator 1 could be replaced by 2 . 2 is not only cheaper then 1 but also more stable and therefore easier to handle. In contrast to 1 polymerization of NVC was observed only if 2 was used in combination with the activating salt.

However, broad molar mass distributions and discrepances between calculated and observed molar masses show that this reaction needs further optimization before it can be applied for a controlled polymerization (Table 5).

\section{EXPERIMENTAL PART}

INSTRUMENTS

IR: Digilab FTS-40; ${ }^{1} \mathrm{H}$ NMR: Bruker AC 250 (250 MHz);

${ }^{13} \mathrm{C}$ NMR: Bruker AC 250 (62,5 MHz); GPC: Waters 510, UV and RI detector (590); calibration with polystyrene' 


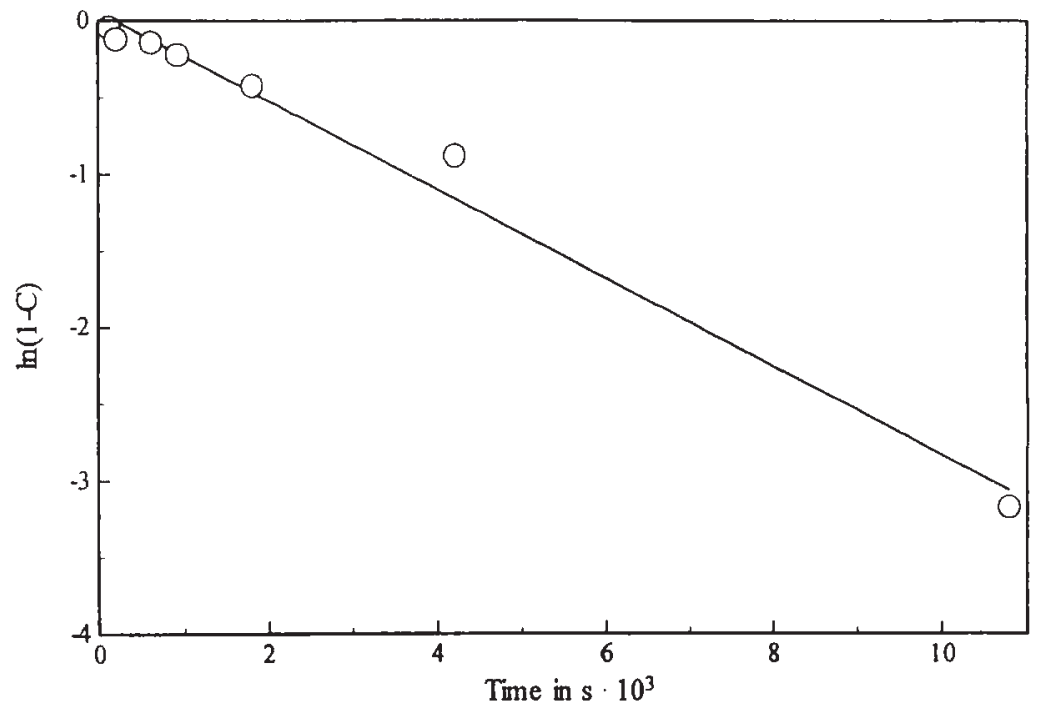

FIG. 5: First order kinetics for the polymerization of NVC with 1 in $\mathrm{CH}_{2} \mathrm{Cl}_{2} /$ toluene $(3: 1)$ at $-50^{\circ} \mathrm{C}$

TABLE 4:

Polymerization of NVC initiated with 1 in $\mathrm{CH}_{2} \mathrm{Cl}_{2}$ /toluene $(3: 1$ (vol.)) $\mathrm{T}=-50^{\circ} \mathrm{C}, t=3,5 \mathrm{~h}$ for each portion of monomer

\begin{tabular}{l|l|l|l|l|l|l} 
& $\begin{array}{l}\text { NVC } \\
\text { mol } 1^{-1}\end{array}$ & $\begin{array}{l}{[1]} \\
10^{3} \text { mol 1 }\end{array}$ & $\begin{array}{l}\mathrm{C} \\
8\end{array}$ & $\begin{array}{l}\mathrm{M}_{\mathrm{n}}(\mathrm{GPC}) \\
\mathrm{g} \mathrm{mol}\end{array}$ & $\begin{array}{l}\mathrm{M}_{\mathrm{n}} \text { (calc) } \\
\mathrm{gmol} \mathrm{mol}^{-1}\end{array}$ & $\mathrm{M}_{\mathrm{w}} / \mathrm{M}_{\mathrm{n}}$ \\
\hline 1.Add. & 0,15 & 8,2 & 100 & 4430 & 3670 & 1,54 \\
\hline 2.Add. & 0,13 & $6,8^{\mathrm{a}}$ & 91 & 6980 & 7030 & 1,43 \\
\hline
\end{tabular}


TABLE 5:

NVC polymerization in $\mathrm{CH}_{2} \mathrm{Cl}_{2}$ initiated by $2 / \mathrm{N}(\mathrm{n}-\mathrm{Bu}){ }_{4} \mathrm{ClO}_{4}$ $[\mathrm{NVC}]=0,5 \mathrm{~mol} 1^{-1},[2]=0,024 \mathrm{~mol} 1^{-1}, t=90 \mathrm{~min}$

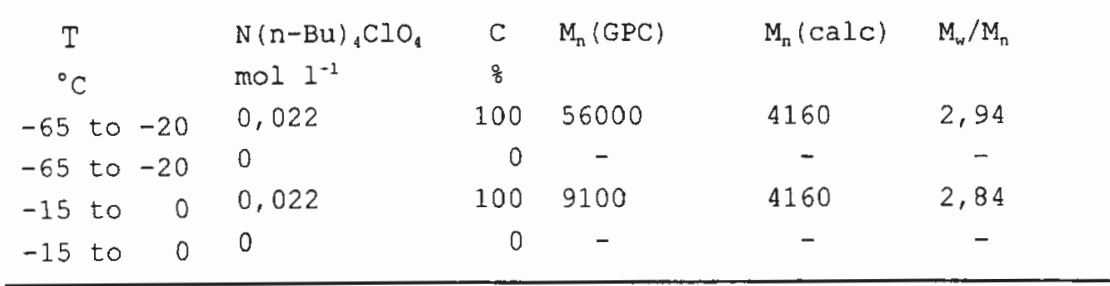

standards, eluation with THF; GC: Varian GC 3700; column CP SIL 5CB, Chrompack 9000: Column CP SII 5CB; Cryostate: Lauda UK 8 DN.

\section{CHEMICALS}

Toluene, xylene were distilled over sodium before use. $\mathrm{CH}_{2} \mathrm{Cl}_{2}$ was refluxed over $\mathrm{CaH}_{2}$ and freshly distilled before each experiments.

$\mathrm{N}$-vinylcarbazol (Fluka) was recrystallized from $\mathrm{n}$ hexane. Isobutylvinyl ether (Fluka) was refluxed over $\mathrm{CaH}_{2}$ and freshly distilled before use. $\mathrm{N}(\mathrm{n}-\mathrm{Bu})_{4} \mathrm{ClO}_{4}$ (Fluka) was dried for 24 hrs under high vacuum conditions and stored under argon.

\section{1-Iodo-1 (2-methylpropyloxy) ethane (1)}

It was synthesized as described in the literature ${ }^{6}$.

\section{1-Chloro-1 (2-methylpropyloxy) ethane (2)}

$\mathrm{HCl}-g a s$ was bubbled through a solution of $16,5 \mathrm{~g}(0,125$ mole) para aldehyde in $27,7 \mathrm{~g}(0,374$ mole) 2-methyl-1propanol for $1 \mathrm{hr}$. Two phases (organic phase and water) are formed at the end of the reaction. The organic phase 
was dried over $\mathrm{CaCl}_{2}$ and then the solvent was distilied off. Yield: $22 \mathrm{~g}\left(43 \frac{\circ}{8}\right)$

b.p. : $38-39^{\circ} \mathrm{C}(30 \mathrm{mbar})$

${ }^{1} \mathrm{H} \operatorname{NMR}\left(\mathrm{CDCl}_{3}\right) \delta(\mathrm{ppm}): 5,05\left(\mathrm{q}, \mathrm{H}^{\mathrm{a}}\right), 3,67\left(\mathrm{dd}, \mathrm{H}^{\mathrm{b}}\right)$, $3,20\left(\mathrm{dd}, \mathrm{H}^{\mathrm{c}}\right), 1,95\left(\mathrm{~m}, \mathrm{H}^{\mathrm{d}}\right), 1,76\left(\mathrm{~d}, \mathrm{H}^{\mathrm{e}}\right), 0,90\left(\mathrm{~d}, \mathrm{H}^{\mathrm{f}}\right)$

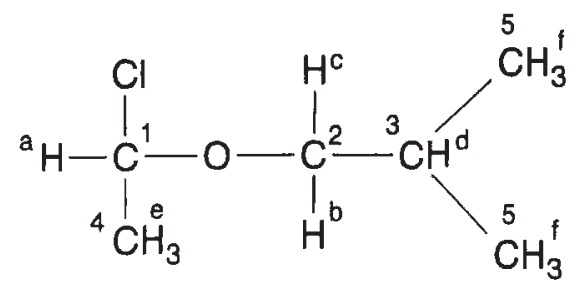

${ }^{13} \mathrm{C}$ NMR $\left(\mathrm{CDCl}_{3}\right) \delta(\mathrm{ppm}): 96,3\left(\mathrm{C}^{1}\right), 77,1\left(\mathrm{C}^{2}\right), 27,9\left(\mathrm{C}^{3}\right)$, $26,7\left(C^{4}\right), 1,91\left(C^{5}\right)$

POLYMERIZATION OF NVC

The thermostated polymerization apparatus equipped with thermostated dropping funnel, 3-way tap, thermometer septum and stirring bar was carefully dried before use (heated to $150^{\circ} \mathrm{C}$ for 12 hrs, cooled under dry argon). Then the apparatus was filled with monomer solvent, activator (if neccassary). The polymerization was started by the addition of prechilled solution of 1 lor 2) in the corresponding solvent.

The reaction temperature was kept constant with a cryostate. Samples were taken through the septum during polymerization.

\section{ACKNOWLEDGEMENT}

The authors wish to thank DSM for financial support and Drs. v.d. Linde and Derks for helpfull discussions. 


\section{REFERENCES:}

1. J. M. Rooney in G. Allen, J. C. Bevington,

G. C. Eastmond, A. Ledwith, S. Russo, P. Sigwalt

(Ed.s) "Comprehensive Polymer Science" Vol. 3,

p. 697, Pergamon Press Oxford 1989

2. D. R. Terrel, F. Evers, J. Polym. Sci. 20, 2529 (1982)

3. T. Higashimura, H. Tearanski, M. Sawamoto, Polym. J. 12, 393 (1980)

4. T. Higashimura, Y. X. Deng, M. Sawamoto, Polym. J. 15, 385 (1983)

5. M. Sawamoto, J. Eujimoni, T. Higashimura, Macromolecules 20, 916 (1987)

6. O. Nuyken, H. Kröner, Makromol. Chem. 191, 1 (1990)

7. O. Nuyken, H. Kröner, S. Aechter, Makromol. Chem. Macromol. Symp. 32, 181 (1990)

8. O. Nuyken, H. Kröner, Polym. Prepr. Am. Chem. Soc. Div. Polym. Chem. 29 (2), 87 (1988)

9. G. Kaszas, J. E. Puskas, C. C. Chen, J. P. Kennedy Macromolecules 23, 3909 (1990)

10. F. J. Burgess, D. H. Richards, Polymer 17, 1020 (1.976)

11. C. V. Freyer, J. Manz, O. Nuyken, Macromol. Chem. Theory and Simul., in print

12. O. Nuyken, G. Rieß, J. A. Loontjens, in preparation 